\title{
12. PRESERVATION OF CALCAREOUS NANNOFOSSILS AND FINE-GRAINED CARBONATE PARTICLES IN MID-CRETACEOUS SEDIMENTS FROM THE SOUTHERN ANGOLA BASIN, SITE 530 1
}

\author{
Peter H. Roth, Department of Geology and Geophysics, University of Utah, Salt Lake City, Utah
}

\begin{abstract}
The upper Albian to Coniacian section (Cores 105 to 89 ) at Site 530 contains rare and poorly preserved coccoliths at a few levels and fine-fraction carbonate ("micarb") at all the levels studied. Dissolution ranking of the most resistant coccolith species is possible. Changes in the dissolution intensity resulting from variations in the organic carbon and carbonate input seem a likely explanation for changes in the relative abundance of fine-fraction carbonates types.
\end{abstract}

\section{INTRODUCTION}

Calcareous nannofossil assemblages recovered from sediments generally record surface water conditions, especially surface water temperature and, to a lesser extent, surface water salinity and nutrient concentrations. Dissolution on the seafloor strongly alters coccolith sediment assemblages and often masks original environmental signals (McIntyre and Bé, 1967; Roth and Berger, 1975; Roth and Coulbourn, 1982). Mid-Cretaceous nannofossil assemblages from cores recovered in the Atlantic, Indian, and Central Pacific oceans have yielded useful information on surface water temperature gradients and fertility, on carbonate dissolution on the seafloor, and on diagenesis within the sediments (Roth and Bowdler, 1981; Roth, 1981; Roth and Krumbach, in prep.). Cyclic changes in surface water conditions and carbonate dissolution during the mid-Cretaceous have been observed (Thierstein and Roth, 1980).

Thus, I planned to study the coccolith assemblages in this long and continuously cored mid-Cretaceous section in order to contribute to a better understanding of paleoceanographic conditions and temporal changes in the Angola Basin.

A cursory look at smear slides prepared from 78 samples of cores recovered from Hole 530A clearly showed that the preservation of nannofossils was very poor; the original assemblages have been so much altered that these assemblages cannot be used to reconstruct the conditions of the surface waters overlying this site where the coccolithophores lived and produced their coccoliths. However, the preservation of coccoliths and other fine carbonate debris provides some insight into carbonate sedimentation, dissolution on the seafloor, and diagenetic processes within the sediment. Therefore, I will briefly describe coccolith preservation using a semiquantitative approach. (See appendix to this chapter for a list of species.)

\footnotetext{
${ }^{1}$ Hay, W. W., Sibuet, J.-C., et al., Init. Repts. DSDP, 75: Washington (U.S. Govt. Printing Office).
}

\section{METHODS}

Smear slides of all samples were prepared by spreading a suspension of a small amount of sediment in distilled water onto a cover glass, then letting it dry on a hot plate. An artificial mounting medium was used to attach the cover glasses to the microscope slides, thus enclosing the sedimentary particles. Visual estimates of sedimentary components were made and are listed on Table 1.

Three different fine-fraction carbonate grains were distinguished: (1) rhombohedra, possibly dolomite; (2) angular fragments; (3) laths. All samples were studied in the light microscope, and the presence of dolomite was not confirmed by X-ray analysis. Counts of coccolith species were made in samples that contained a sufficient number of coccoliths. A total of 300 specimens were counted whenever possible. In a few very poor samples, a total count of only 200 specimens was achieved. In samples that contained only a few specimens per longitudinal traverse of slide, only estimates of the relative abundances of nannofossil species are given. Coccolith counts are shown on Table 2.

\section{RESULTS}

The mid-Cretaceous portion of the sedimentary section at Site 530 consists of interbedded green, gray, and red mudstones, siltstones, marlstones, limestones, and black shales resting on basalt. Calcium carbonate content varies from less than $1 \%$ to $82 \%$ but is generally under $50 \%$. The section from Core 89 to Core 105 contains chalk, marlstone, claystone, and black shale. Shipboard scientists interpreted this sequence as the basin facies of a submarine fan composed of distal turbidites. They considered the presence of red claystones as indicative of oxygenated bottom waters and regarded the green and gray layers as evidence of secondary reduction resulting from oxygen consumption in organic-carbonrich "black shale" layers.

Fine-fraction carbonate particles in Cores 105 and 103 consist largely of rhombohedra of 1 to $5 \mu \mathrm{m}$ and fewer angular fragments. Recognizable nannofossils were observed in Core 105, Section 3 at $24-25 \mathrm{~cm}$. The coccoliths have been badly etched and make up $5 \%$ of the sediment. Placoliths (Watznaueria barnesae) make up the bulk of the coccolith fraction (Table 2).

Section 102-3 contains rare nannofossils at 143-144 $\mathrm{cm}$. The assemblage still consists largely of placoliths, but Lithastrinus floralis, a very robust species, also is quite common. Sections 2 and 1 of Core 102 contain the best preserved and most diverse coccolith assemblage 
Table 1. Visual estimates of carbonate particles, Hole 530A.

\begin{tabular}{|c|c|c|c|c|c|c|}
\hline \multirow[b]{2}{*}{$\begin{array}{c}\text { Sample } \\
\text { (level in } \mathrm{cm} \text { ) }\end{array}$} & \multirow{2}{*}{$\begin{array}{c}\text { Nannofossil } \\
\text { zone } \\
\text { and age }{ }^{\mathrm{a}}\end{array}$} & \multirow{2}{*}{$\begin{array}{c}\text { Abundance/ } \\
\text { preservation } \\
\text { of nannofossils }\end{array}$} & \multicolumn{3}{|c|}{$\begin{array}{c}\text { Abundance of carbonate } \\
\text { particles }(\%)\end{array}$} & \multirow{2}{*}{$\begin{array}{l}\text { Predominant } \\
\text { micarb } \\
\text { components }\end{array}$} \\
\hline & & & Coccoliths & Micarb & $\begin{array}{c}\text { Non- } \\
\text { carbonate }\end{array}$ & \\
\hline $89-1,84$ & NC 15 Coniacian & $\mathrm{C} / \mathrm{M}, \mathrm{E} 2 / \mathrm{O}_{2}$ & 30 & 40 & 30 & A \\
\hline $89-1,93$ & NC 15 Coniacian & $\mathrm{R} / \mathrm{P}, \mathrm{E} 3 / \mathrm{O}_{2}$ & 0.1 & 2 & 98 & A \\
\hline $89-1,104$ & NC 15 Coniacian & $\mathrm{F} / \mathrm{P}, \mathrm{E} 3 / \mathrm{O}_{2}$ & 20 & 40 & 40 & A \\
\hline $89-1,116$ & NC 15 Coniacian & $\mathrm{F} / \mathrm{M}, \mathrm{E} 3 / \mathrm{O}_{2}$ & 25 & 45 & 30 & R, A \\
\hline $89-1,124$ & $?$ & $\mathrm{R} / \mathrm{P}, \mathrm{E} 3 / \mathrm{O}_{2}$ & 0.1 & 10 & 90 & R, A \\
\hline $89-1,136$ & $?$ & $\mathrm{VB}, \mathrm{E} 3 / \mathrm{O}_{2}$ & 0.1 & 2 & 98 & A, R \\
\hline $90-3,52$ & $?$ & B & 0 & 2 & 98 & R, A \\
\hline $90-3,84$ & $?$ & B & 0 & 3 & 97 & $\mathrm{R}, \mathrm{A}$ \\
\hline $90-3,106$ & $?$ & B & 0 & 3 & 97 & R, A \\
\hline $95-2,21$ & NC 13 Turonian & $\mathrm{F} / \mathrm{P}, \mathrm{E} 3 / \mathrm{O}_{2}$ & 1 & 5 & 94 & R, A \\
\hline $95-2,43$ & $?$ & B & 0 & 1 & 99 & R, A \\
\hline $95-2,64$ & ? & B & 0 & i & 99 & R, A \\
\hline $95-2,89$ & ? & B & 0 & 8 & 92 & R, A \\
\hline $95-2,110$ & $?$ & $\mathrm{R} / \mathrm{P}, \mathrm{E} 3 / \mathrm{O}_{2}$ & 0.1 & 1 & 99 & $\mathrm{R}, \mathrm{A}$ \\
\hline $95 \cdot 2,130$ & $?$ & B & 0 & 5 & 95 & $R, A, N$ \\
\hline $95-2,149$ & NC 13 Turonian & $\mathrm{VB}, \mathrm{E} 3 / \mathrm{O}_{2}$ & 0.1 & 5 & 95 & $\mathrm{R}, \mathrm{A}$ \\
\hline $97-1,128$ & $?$ & B & 0 & 2 & 98 & R \\
\hline $99-1,146$ & ? & B & 0 & 3 & 97 & $\mathbf{R}$ \\
\hline $97-2,20$ & $?$ & B & 0 & 5 & 95 & R \\
\hline $97-2,40$ & $?$ & B & 0 & 5 & 95 & $\mathrm{R}$ \\
\hline $97-2,60$ & ? & B & 0 & 5 & 95 & $\mathbf{R}$ \\
\hline $97-2,80$ & $?$ & B & 0 & 10 & 90 & R \\
\hline $97-2,120$ & ? & B & 0 & 2 & 98 & R, N \\
\hline $97-2,149$ & ? & B & 0 & 2 & 98 & R \\
\hline $97-2,130$ & ? & B & 0 & 10 & 90 & $\mathbf{R}$ \\
\hline $98-2,145$ & $?$ & B & 0 & 10 & 90 & $\mathbf{R}$ \\
\hline $98-3,38$ & $?$ & B & 0 & 1 & 99 & $A, R$ \\
\hline $98-3,43$ & ? & B & 0 & 5 & 95 & R \\
\hline $98-3,87$ & ? & B & 0 & 10 & 90 & $\mathbf{R}$ \\
\hline $98-3,99$ & ? & B & 0 & 10 & 90 & $\ddot{R}$ \\
\hline $99-3,107$ & $?$ & vB & 0.1 & 30 & 70 & $\mathrm{R}, \mathrm{A}$ \\
\hline $99-3,126$ & $\begin{array}{l}\text { NC } 10-12 \text { late } \\
\text { Albian to e. Turonian }\end{array}$ & F/P & 20 & 40 & 40 & A \\
\hline $99-3,146$ & $?$ & B & 0 & 5 & 95 & $\mathbf{R}$ \\
\hline $99-4,20$ & $?$ & B & 0 & 15 & 85 & R \\
\hline $99.4,39$ & ? & B & 0 & 10 & 90 & $\mathbf{R}$ \\
\hline $99-4,60$ & ? & B & 0 & 8 & 92 & $A, R$ \\
\hline $99-4,78$ & ? & B & 0 & 5 & 95 & $\mathrm{R}, \mathrm{A}$ \\
\hline $99-4,100$ & $?$ & B & 0 & 15 & 85 & R, A \\
\hline $99-4,123$ & ? & VB & 0.1 & 10 & 90 & R \\
\hline $100-1,87$ & ? & B & 0 & 10 & 90 & $\mathbf{R}$ \\
\hline $100-1,112$ & ? & B & 0 & 3 & 97 & $A, R$ \\
\hline $100-1,122$ & $?$ & $R / P$ & 10 & 45 & 45 & $A, R$ \\
\hline $100-1,142$ & $?$ & VB & 0.1 & 10 & 90 & A \\
\hline $100-2,37$ & $\begin{array}{l}\text { NC 10-11 1. Albian } \\
\text { e. Cenomanian }\end{array}$ & $\mathrm{R} / \mathrm{P}, \mathrm{E} 2 / \mathrm{O}_{3}$ & 10 & 10 & 70 & A \\
\hline $100-2,58$ & $?$ & VB & 0.1 & 5 & 95 & A \\
\hline $100-2,78$ & $?$ & B & 0 & 5 & 95 & A \\
\hline $100-2,98$ & $?$ & $\mathrm{R} / \mathrm{P}$ & 1 & 20 & 79 & A \\
\hline $100-2,119$ & $\begin{array}{l}\text { NC 10-11 l. Albian } \\
\text { e. Cenomanian }\end{array}$ & $\mathrm{R} / \mathrm{P}, \mathrm{E}_{3} / \mathrm{O}_{2}$ & 10 & 45 & 45 & A \\
\hline $102-1,60$ & $\begin{array}{l}\text { NC 10-11 I. Albian } \\
\text { c. Cenomanian }\end{array}$ & $R / P, E_{3} / O_{2}$ & 10 & 80 & 10 & A \\
\hline $102-1,79$ & $\begin{array}{l}\text { NC 10-11 1. Albian } \\
\text { e. Cenomanian }\end{array}$ & $\mathrm{R} / \mathrm{P}, \mathrm{E}_{3} / \mathrm{O}_{2}$ & 2 & 5 & 93 & A \\
\hline $102-1,100$ & $\begin{array}{l}\text { NC 10-11 I. Albian } \\
\text { e. Cenomanian }\end{array}$ & $\mathrm{R} / \mathrm{P}, \mathrm{E}_{3} / \mathrm{O}_{2}$ & 2 & 40 & 58 & A \\
\hline $102-1,120$ & $\begin{array}{l}\text { NC 10-11 I. Albian } \\
\text { e. Cenomanian }\end{array}$ & $\mathrm{F} / \mathrm{P}, \mathrm{E}_{3} / \mathrm{O}_{2}$ & 25 & 45 & 30 & A \\
\hline $102-1,142$ & $\begin{array}{l}\text { NC 10-11 1. Albian } \\
\text { c. Cenomanian }\end{array}$ & $\mathrm{R} / \mathrm{P}, \mathrm{E}_{3} / \mathrm{O}_{2}$ & 5 & 20 & 75 & A \\
\hline $102-2,16$ & $\begin{array}{l}\text { NC jo-111. Albian } \\
\text { e. Cenomanian }\end{array}$ & $\mathrm{F} / \mathrm{P}, \mathrm{E}_{3} / \mathrm{O}_{2}$ & 25 & 45 & 30 & $A, R$ \\
\hline $102-2,29$ & $\begin{array}{l}\text { NC 10-11 1. Albian } \\
\text { e. Cenomanian }\end{array}$ & $\mathrm{F} / \mathrm{P}, \mathrm{E}_{3} / \mathrm{O}_{2}$ & 20 & 60 & 20 & A, $R$ \\
\hline $102-2,49$ & $\begin{array}{l}\text { NC 10-11 I. Albian } \\
\text { e. Cenomanian }\end{array}$ & $\mathrm{F} / \mathrm{P}, \mathrm{E}_{3} / \mathrm{O}_{2}$ & 15 & 30 & 55 & A, $R$ \\
\hline $102-2,68$ & $\begin{array}{l}\text { NC 10-11 1. Albian } \\
\text { e. Cenomanian }\end{array}$ & $\mathrm{F} / \mathrm{P}, \mathrm{E}_{3} / \mathrm{O}_{2}$ & 20 & so & 30 & A \\
\hline $102-2,92$ & $\begin{array}{l}\text { NC 10-11 1. Albian } \\
\text { e. Cenomanian }\end{array}$ & $\mathrm{F} / \mathrm{P}, \mathrm{E}_{3} / \mathrm{O}_{2}$ & 20 & 45 & 45 & A \\
\hline $102-3,103$ & $\begin{array}{l}\text { NC 10-111. Albian } \\
\text { e. Cenomanian }\end{array}$ & $\mathrm{F} / \mathrm{P}, \mathrm{E}_{3} / \mathrm{O}_{2}$ & 20 & 60 & 20 & A \\
\hline $102-3,126$ & $?$ & B & 0 & 20 & 80 & R \\
\hline $102-3,143$ & $\begin{array}{l}\text { NC 10-11 I. Albian } \\
\text { e. Cenomanian }\end{array}$ & $\mathrm{R} / \mathrm{P}, \mathrm{E}_{3} / \mathrm{O}_{2}$ & 20 & so & 30 & A \\
\hline $103-1,100$ & $?$ & VB & 0.1 & 10 & 90 & A \\
\hline $103-4,86$ & ? & B & 0 & 10 & 90 & R, A \\
\hline $105-2,12$ & $?$ & B & 0 & 5 & 95 & R, A \\
\hline $105-2,31$ & ? & B & 0 & 15 & 85 & $\mathrm{R}, \mathrm{A}$ \\
\hline $105-2,49$ & ? & B & 0 & 5 & 95 & $\mathrm{R}, \mathrm{A}$ \\
\hline $105-2,64$ & ? & B & 0 & 1 & 99 & R \\
\hline $105-2,78$ & ? & B & 0 & s & 95 & $\widehat{R}$ \\
\hline $105-2,95$ & $?$ & B & 0 & i & 99 & R, A \\
\hline $105-2,115$ & $?$ & B & 0 & 1 & 99 & $\mathbf{R}$ \\
\hline $105-2,138$ & $?$ & B & 0 & 5 & 95 & $\mathbf{R}$ \\
\hline $105-3,24$ & $\begin{array}{l}\text { NC 10-11 1. Albian } \\
\text { e. Cenomanian }\end{array}$ & $R / P, E_{3}$ & 5 & 35 & 60 & $A, R$ \\
\hline $105-3,42$ & ? & B & 0 & 10 & 90 & A, $R$ \\
\hline $105-3,65$ & ? & B & 0 & 15 & 85 & R \\
\hline $105-3,83$ & ? & B & 0 & 5 & 95 & $\mathbf{R}$ \\
\hline $105-3,122$ & ? & B & 0 & 3 & 97 & R, A \\
\hline $105-3,142$ & ? & B & 0 & 3 & 97 & A. $R$ \\
\hline
\end{tabular}


Table 2. Relative abundance of coccoliths, Hole 530A.

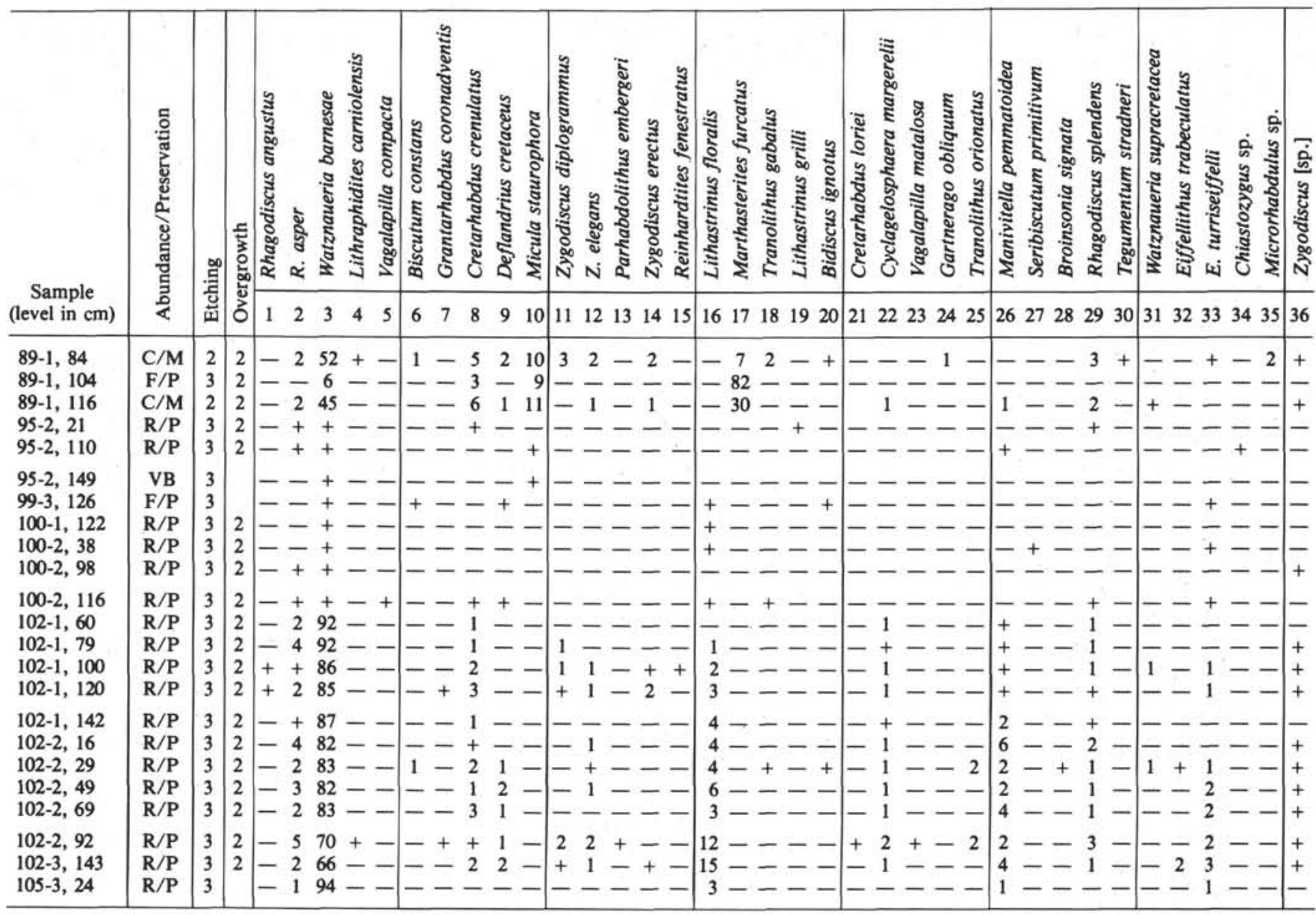

Note: The plus symbol means that the species is present; the dash indicates that the species was looked for but not found; the numbers indicate percent of the total assemblage.

with the exception of Core 89. Placoliths still predominate and contribute between 70 and $92 \%$ to the total assemblage. Observations in cores from the Atlantic and Indian oceans clearly show that nannofossil assemblages with over $40 \%$ of $W$. barnesae have been severely affected by dissolution and also have a low diversity and overall poor preservation of the coccoliths (Roth and Bowdler, 1981; Roth and Krumbach, in prep.) The assemblages from Sections 1, 2, and 3 of Core 102 all have $W$. barnesae percentages well above the value of $40 \%$ that separates slightly to moderately dissolved from heavily dissolved samples. Also, diversities are low, generally less than 15 species per sample; well-preserved samples generally contain 20 to 30 species. Even these best preserved samples are but meager dissolution residua of the original biocoenoses and are thus not useful for the reconstruction of surface water conditions. The fine carbonate fraction makes up a large proportion of the sediments (generally between 20 and 50\%) in Core 102, Sections 1 to 3 ; it consists largely of angular fragments and a few rhombohedra. The age of Cores 102 and 100 is late Albian to early Cenomanian based on the presence of Eiffellithus turriseiffeli and the absence of Micula staurophora.
Core 100 , Sections 1 and 2 contain rare and poorly preserved coccolith assemblages that are dominated by $W$. barnesae but are generally too poorly preserved and too rare for a quantitative floral analysis. The fine carbonate fraction is considerably less important in Core 100 and generally amounts to $5-20 \%$; only two samples contain $45 \%$ fine carbonate. Angular fragments dominate over rhombohedra. Section 2 of Core 100 is late Albian to early Cenomanian; all other samples from Core 100 lack age-diagnostic nannofossils and cannot be assigned to a nannofossil zone.

Core 99, Sections 3 and 4 lack nannofossils entirely, except for one sample that contains a few placoliths and nannofossil fragments. The fine-grained carbonate fraction amounts to less than one-fifth of the total sediment volume in most samples. Carbonate rhombohedra predominate over angular fragments. The age of this interval is not known exactly but appears to be early Turonian to late Albian, as it lies between dated intervals. Cores 98 and 97 are all barren of nannofossils and contain $10 \%$ or less fine-grained carbonate, generally in the form of rhombohedra, $2-5 \mu \mathrm{m}$ in size, and few angular fragments and laths. Core 95, Section 2 contains few to very rare coccoliths. Placoliths are dominant in all as- 
semblages. The presence of Micula staurophora indicates a late Turonian age. Fine-grained carbonate consists of a mixture of angular fragments and rhombohedra and amounts to $1-8 \%$ of the total sediment volume.

Core 90, Section 3 lacks coccoliths, but contains 2$5 \%$ fine-grained carbonate in the form of rhombohedra and angular fragments. Core 89 , Section 1 contains moderately well-preserved coccolith assemblages near the top and is virtually barren near the base. It shows very interesting changes in the coccolith assemblages. The most dissolved assemblage (at $104 \mathrm{~cm}$ ) consists largely of Marthasterites furcatus, which seems enriched by an order of magnitude compared to the best preserved assemblage $(84 \mathrm{~cm}) . W$. barnesae shows the opposite trend. It makes up over $50 \%$ of the best preserved assemblage but only $6 \%$ of the most poorly preserved assemblage. Micula staurophora is somewhat enriched in the more dissolved assemblage. Thus, in the Coniacian, Marthasterites furcatus is the most solution-resistant species, followed by Micula staurophora and $W$. barnesae. All other species are less solution resistant, but are not sufficiently abundant to be ranked using such a small sample set. The fine-grained carbonate fraction ranges from 2 to $45 \%$, and angular fragments generally dominate over rhombohedral particles. The presence of Marthasterites furcatus is indicative of a Coniacian to Santonian age for Core 89.

\section{DISCUSSION}

The upper Albian to Coniacian section at Site 530 generally lacks nannofossils or contains only rare nannofossils and a variable proportion of fine-grained fraction carbonate. Several intervals of improved carbonate preservation are observed: namely, a weak one in Core 105 , a more pronounced one in Core 102, and weak ones in Cores 100, 99, and 95.

In Core 89 carbonate preservation improves drastically in Section 1. It is quite clear that the percent of finefraction carbonate (unidentified fragments and rhombohedra) also is increased where nannofossils are more abundant. There is a tendency for angular carbonate fragments rather than rhombohedra to predominate in the "micritic carbonate" fraction where nannofossils are abundant. The most carbonate-poor intervals contain largely rhombohedra. It seems likely that rhombohedra survive dissolution best and may form within the sediment in these intervals of lowest carbonate concentration. They are probably largely dolomite that formed in situ as a decrease with depth in the magnesium concentration in the pore waters would indicate (see site summary). These rhombohedra are the most dissolutionresistant carbonates. Different degrees of dissolution allow a ranking of the most resistant Coniacian nannofossil species (from most to least resistant): Marthasterites furcatus, Micula staurophora, and Watznaneria barnesae. In the older sediments, $W$. barnesae seems most resistant followed by Lithastrinus floralis.

These preservation pulses of carbonate would indicate that the site of deposition of this section was close to the calcite compensation depth (CCD) during the late Albian to Coniacian. Perhaps fluctuating input of pelagic carbonate and organic matter (largely of marine origin) resulted in various degrees of undersaturation of pore waters with respect to calcite. Catabolic breakdown of organic matter in the sediment increased the dissolved $\mathrm{CO}_{2}$ concentration in the pore waters. This resulted in changes in coccolith and fine-fraction carbonate preservation. This process would eliminate the need for slight CCD fluctuations. Variable inputs of shallow-water-derived carbonates could also buffer the pore waters to various degrees and result in changes of preservation of fine-fraction carbonates. Although the nannofossil assemblages are poor at Site 530, there are no indications of redeposition of shallow-water nannofossil oozes into deeper water, and I consider the nannofossils to be largely a pelagic contribution to the sediment from the overlying water. Some of the angular carbonate fragments might be redeposited and most of the rhombohedra are probably dolomite and seem to have formed in situ.

Although dissolution has strongly altered the nannofossil assemblages and rendered them useless for the reconstruction of surface water conditions, they are a most sensitive dissolution indicator. Carbonate dissolution was strong at all times during the mid-Cretaceous but not strong enough to dissolve (dolomite) rhombohedra. Dissolution intensity fluctuated from the Albian to the Coniacian, probably because of changes in organic carbon and carbonate input, which were strongly influenced by surface water fertility. The Coniacian was a time of higher carbonate accumulation and preservation. Most of the late Albian to Cenomanian was a time of carbonate dissolution at this site.

\section{ACKNOWLEDGMENTS}

This research was supported by National Science Foundation grant OCE 76-21561, and the samples used were recovered through the assistance of the National Science Foundation. I thank W. W. Hay (University of Colorado), J.-C. Sibuet (Centre Oceanologique de Bretagne), and all the other shipboard scientists on Leg 75 for letting me study these samples and for providing valuable background information. I am grateful to A. A. Ekdale (University of Utah) and K. R. Krumbach (Gulf Oil Company) for critical reviews of this paper.

\section{REFERENCES}

McIntyre, A., and Bé, A. W. H, 1967. Modern Coccolithophoridae of the Atlantic Ocean-I. Placoliths and cyrtoliths. Deep-Sea Res., 14:561-597.

Roth, P. H., 1978. Cretaceous nannoplankton biostratigraphy and oceanography of the northwestern Atlantic Ocean. In Benson, W. E., Sheridan, R. E., et al., Init. Repts. DSDP, 44: Washington (U.S. Govt. Printing Office), 731-759.

1981. Mid-Cretaceous calcareous nannoplankton from the Central Pacific: Implications for paleoceanography. In Thiede, J., and Vallier, T. L., et al., Init. Repts. DSDP, 62: Washington (U.S. Govt. Printing Office), 471-489.

Roth, P. H., and Berger, W. H., 1975. Distribution and dissolution of coccoliths in the South and Central Pacific. Cushman Foundation Foram. Res., Spec. Publ., 13:87-113.

Roth, P. H., and Bowdler, J. L., 1981. Middle Cretaceous calcareous nannoplankton: Biogeography and oceanography of the Atlantic Ocean. Soc. Econ. Paleontol. Mineral., Spec. Publ., 32:517-546.

Roth, P. H., and Coulbourn, W. T., 1982. Floral and solution patterns in surface sediments of the North Pacific. Mar. Micropaleontol., $7: 1-52$.

Thierstein, H. R., and Roth, P. H., 1980. Stable isotopes and biogeography of mid-Cretaceous microfossils. 26th Int. Geol. Cong., Paris, p. 293. (Abstract)

Date of Initial Receipt: September 21, 1982 


\section{APPENDIX \\ List of Species \\ (in alphabetical order by species epithet)}

Rhagodiscus angustus (Stradner, 1963) Reinhardt, 1971.

$R$. asper Stradner, 1963) Reinhardt, 1967.

Watznaueria barnesae (Black, 1959) Perch-Nielsen, 1968.

Lithraphidites carniolensis Deflandre, 1963.

Vagalapilla compacta Bukry, 1969.

Biscutum constans (Gorka, 1957) Black, 1967.

Grantarhabdus coronadventis (Reinhardt, 1966) Grün, 1975.

Deflandrius cretaceus (Arkhangelsky, 1912) Bramlette and Martini, 1964.

Zygodiscus diplogrammus (Deflandre 1954), Gartner, 1968.

Zygodiscus elegans Gartner, 1968.

Parhabdolithus embergeri (Nöel, 1959) Stradner, 1963.

Z. erectus (Deflandre, 1954) Manivit, 1971.

Reinhardtites fenestratus Worsley, 1971) Thierstein, 1972.

Lithastrinus floralis Stradner, 1962.

Marthasterites furcatus (Deflandre, 1954) Delfandre, 1959.

Tranolithus gabalus Stover, 1966.
Lithastrinus grillii Stradner, 1962.

Bidiscus ignotus (Gorka, 1957) Hoffmann, 1970.

Cretarhabdus loriei Gartner, 1968.

Cyclagelosphaera margerelii Noël, 1965.

Vagalapilla matalosa (Stover, 1966) Thierstein, 1973.

Gartnerago obliquum (Stradner, 1963) Reinhardt, 1970.

Tranolithus orionatus (Reinhardt, 1966) Reinhardt, 1966.

Manivitella pemmatoidea (Deflandre ex Manivit, 1965) Thierstein, 1971.

Seribiscutum primitivum (Thierstein, 1974) Filewicz, Wind and Wise, 1977.

Broinsonia signata (Noël, 1969) Noël, 1970.

Rhagodiscus splendens (Deflandre, 1954) Verbeek, 1977.

Micula staurophora (Gardet, 1955) Stradner, 1963.

Tegumentum stradneri Thierstein, 1972.

Watznaueria supracretacea (Reinhardt, 1965) Perch-Nielsen, 1968.

Eiffellithus trabeculatus (Gorka, 1957) Reinhardt and Gorka, 1967.

E. turriseiffelii (Deflandre, 1954) Reinhardt, 1965.

Chiastozygus Gartner, 1968.

Microrhabdulus Deflandre, 1959.

Zygodiscus Bramlette and Sullivan, 1961. 